\title{
TINJAUAN HUKUM DAN PERAN PEMERINTAH DALAM TINDAK PIDANA PERDAGANGAN ORANG (TPPO) DI KABUPATEN KARIMUN DAN KOTA BATAM
}

\author{
Dhani Akbar \\ Program Studi Hubungan Internasional \\ Fakultas IImu Sosial dan IImu Politik Universitas Maritim Raja Ali Haji \\ Email : rittersarmy@gmail.com \\ Indrawan \\ Fakultas IImu Sosial dan IImu Politik Universitas Karimun \\ Email : indrawan.up@gmail.com
}

\begin{abstract}
Human trafficking can be classified as one of the worst forms of abuse experienced by human history. Number of the case, regional to international levels, show an increasing trend. Therefore, Indonesia as a part of the world community whose citizens are one of the most victims of human trafficking, seeks to enforce the law and maintain the role as a form of preventive action against the outbreak of Human Trafficking. Local government which is directly contacted with the issue of human trafficking should have strategy to solve the problem. The concept of sustainability fulfillment of security, roles and functions of continuous supervision by local governments is an integral part of the Indonesian constitution, the weakness of the role and supervision of strategy of local government, will increase the problem of social and law. Therefore, there must be joint efforts with other countries. Thus, inter-governmental cooperation, inter-NGO, mass organizations and individuals which are well developed and the synchronization of policy become imperative. Whereas for eradication measures a repressive effort is conducted through coordination among law enforcers which are part of integrated criminal justice system. This is in order to the realization of law enforcement.
\end{abstract}

Keywords: Government Role, Crime, Human Trafficking, Law

\begin{abstract}
Abstrak
Indonesia sebagai bagian dari masyarakat dunia yang warganya merupakan salah satu terbanyak menjadi korban trafficking berupaya untuk melakukan penegakan hukum dan tindakan serta peran sebagai bentuk tindakan preventif atas merebaknya tindak pidana (TPPO) dimaksud, Pemerintah daerah sebagai perwakilan pemerintah yang pertama kali bersentuhan lansung dengan persoalan kejahatan perdagangan orang, harusnya mempunyai langkah Strategis yang langsung menyentuh akar persoalan terhadap korban trafficking. Konsep pemenuhan perlindungan, peran dan fungsi pengawasan yang berkelanjutan oleh pemerintah daerah. ini merupakan bagian dari yang tidak terpisahkan didalam konstitutional Indonesia, jangan sampai dengan lemahnya peran dan pengawasan serta langkah strategis dari pemerintah daerah, akan menambah persoalan mulai dari sosial dan hukum selain memeranginya di dalam negeri maka harus ada upaya bersama dengan negara lain. Maka kerjasama antar pemerintah, antar-NGO, ormas dan perseorangan dalam dan luar negeri yang dibina dan dikembangkan dengan baik serta sinkronisasi kebijkan menjadi keharusan. sedangkan untuk tindakan pemberantasan dilakukan upaya represif melakukan kerjasama melalui koordinasi antar lembaga penegak hukum yang merupakan bagian dari sistem peradilan pidana terpadu. Hal itu demi terwujudnya penegakan hukum.
\end{abstract}

Kata kunci: Peran Pemerintah, Kriminal, Perdagangan Manusia, Hukum 


\section{Pendahuluan}

\subsection{Latar Belakang Masalah}

Permasalahan Perdagangan manusia adalah isu laten yang mendapat perhatian dari semua pihak. Pemerintah harus serius dan bekerja keras agar angka perdagangan manusia dapat dihilangkan. Namun hal ini menimbulkan permasalahan baru ketika disatu sisi pemerintah serius untuk menangani permasalahan perdagangan manusia dengan membuat kebijakankebijakan pencegahan dan penanganan korban perdagangan manusia. Namun disisi lain pemerintah juga membuka keran pengiriman buruh migran ke luar negeri, dimana hal ini menjadi peluang atau salah satu faktor penyebab terjadinya trafficking atau perdagangan manusia.

Tercatat kurang lebih terdapat 10 Peraturan Perundang-Undangan yang dibuat dari tingkat nasional hingga daerah sebagai political will dari pemerintah untuk mencegah dan menangani permasalahan ini, namun faktanya adanya political will dari pemerintah belum membawa perubahan yang signifikan. Dalam berbagai studi dan laporan dari sejumlah LSM menyatakan bahwa Indonesia masih merupakan daerah sumber trafficking, disamping juga sebagai transit dan penerima perdagangan manusia. Sedikitnya diidentifikasi 10 provinsi di Indonesia yang dijadikan sebagai sumber, 16 provinsi dijadikan sebagai tempat transit, dan sedikitnya 12 provinsi sebagai penerima. Belum ditemukan jumlah yang akurat untuk jumlah perempuan dan anak korban trafficking di Indonesia.Data yang tersedia beragam dari 74.616 orang hingga 1 juta pertahun.
Perdagangan manusia adalah salah satu kejahatan kemanusiaan, karena jelas permasalahan ini melangggar Hak Asasi Manusia. Adapun beberapa contoh hak asasi yang dilanggar diantaranya adalah, hak atas hidup (right to life); hak untuk tidak di siksa (no one shall be subjected to torture); hak atas kebebasan dan keamanan dirinya (right to liberty and security of person); hak atas kesamaan di muka badan-badan peradilan (right to equality before the court and tribunals...".1

Jumlah perempuan dan anak yang menjadi korban trafficking sudah tidak terhitung lagi. Selain kerena begitu banyak perempuan dan anak yang menjadi korban, juga tidak pernah ada data kongkrit untuk keseluruhan data trafficking di Indonesia. Menurut data yang dikeluarkan oleh International Organization for Migration (IOM), kasus perdagangan manusia di Indonesia semakin mencengangkan. Data yang dirilis pada tahun 2011, Indonesia menempati peringkat teratas dengan jumlah 3.943 korban perdagangan manusia. Selain itu Setidaknya 90,3\% korban tindak pidana perdagangan orang adalah perempuan dan $23,6 \%$ anak-anak, yang merupakan kelompok rentan terhadap kekerasan.

Menurut laporan tahunan yang dirilis oleh Kedutaan Besar Amerika di Indonesia, sekitar 1,94,7 juta Warga Negara Indonesia bekerja di luar negeri, kebanyakan di antaranya tidak memiliki izin tinggal dan atau sudah melewati batas yang telah ditentukan. Menurut data, sekitar 199 orang telah ditangkap dan 5.668 orang yang diduga menjadi korban perdagangan manusia telah dipulangkan ke tanah air. Menurut data pada tahun 2015, sekitar

1 Miriam Budiardjo, Dasar-Dasar IImu Politik, PT. Gramedia Pustaka Indonesia, Jakarta: 2000. HIm. 16 
221 kasus telah ditangani dan 165 telah divonis bersalah, dan setahun sebelumnya, 2014, sebanyak 305 kasus dan yang telah diadili adalah sekitar 134 kasus. Menurut data, 1.500 orang dipaksa bekerja di sector perikanan di Luar Negeri, 97 di Rumah Tangga, dan 10 di pabrik. Menurut hasil tersebut, 1.322 orang telah diserahkan melalui Pemerintah, LSM, dan Pengacara. Di mana LSM melanjutkan korban-korban tersebut ke penampungan dan penyedia pelayanan kesehatan. Kebanyakan korban Arab Saudi, Bahrain, Iran dll.

Menurut data IOM, sekitar $6.651 \mathrm{WNI}$ adalah $82 \%$ adalah perempuan yang bekerja di dalam dan luar negeri. Selanjutnya, jawa Barat masih menjadi penyumbang terbesar Perdagangan manusia dengan 32,35\% diikuti oleh Jawa Tengah $13,67 \%$ dan Kalimantan Barat 11\%. Yang mana jumlah tersebut akan dikirim ke Luar Negeri dan sebagian besar juga ke beberapa provinsi besar di Indonesia seperti Jakarta, Kepri, Sumatera Utara, dan lain-lain. Dalam konteks Provinsi Kepri, Batam menjadi kota ke dua sebagai penyalur, dan terdapat retusan jaringan perdagangan yang tersebar di Bintan, Batam, Karimun dan Tanjungpinang ${ }^{2}$ Data konkret mengenai Perdagangan manusia dapat diperoleh dari LSM seperti Embun pagi, GAT, KKPPMP, Forum HAM Perempuan dan Rumah Faye.

Eksploitasi seksual dan tenaga kerja, baik yang terdokumentasi atau tidak, sadar atau tidak, legal maupun illegal, yang terjadi pada perempuan dan anak malalui perdagangan manusia merupakan kejahatan kemanusiaan yang melanggar Hak Asasi
Manusia. Karimun merupakan kabupaten dengan peningkatan jumlah korban yang ditampung untuk kemudian diteruskan ke luar negeri setiap tahunnya. Dalam penelitian ini dibahas bagaimana peran dan koordinasi pemerintah dalam mencegah dan menanggulangi kasus perdagangan manusia di kabupaten Karimun dan Kota Batam dan bagaimana tinjauan hukum dalam kasus perdagangan manusia.

\subsection{Rumusan Masalah}

1. Bagaimana pengawasan pemerintah daerah dalam mencegah dan menanggulangi kasus perdagangan manusia di Kabupaten Karimun dan Kota Batam?

2. Bagaimana tinjauan hukum dalam kasus perdagangan manusia di Kabupaten Karimun dan Kota Batam?

\section{Tinjauan Teori}

\subsection{Pemerintah Daerah}

Pemerintahan apabila dibagi atau dipisahkan, maka terdapat perbedaan antara pemerintahan dalam arti luas dan pemerintahan dalam arti sempit. ${ }^{3}$ Pemerintahan dalam arti sempit hanya meliputi lembaga yang mengurusi pelaksanaan roda pemerintahan (disebut eksekutif), sedangkan pemerintahan dalam arti yang luas selain eksekutif, termasuk lembaga yang membuat peraturan perundang-undangan (disebut legislatif), dan yang melaksanakan peradilan (disebut yudikatif). ${ }^{4}$

\footnotetext{
Kementerian Pemberdayaan Perempuan dan Perlindungan Anak 2017.

Murhaini Suriansyah, Manajemen Pengawasan Pemerintah Daerah, Pustaka Pelajar, Jakarta: 2014. HIm. 5.

Inu Kencana, Pengantar IImu Pemerintahan, Refika Aditama, Bandung: 2005. HIm. 22-25.
} 
Menurut C.F. Strong sebagaimana dikutip oleh Inu Kencana Syafie (2005:22) :

Government in the broader sense, is changed with the maintenance of the peace and security of state with in and with out. It must therefore, have first military power or the control of armed forces, secondly legislative power or the means of making law, thirdly financial power of the ability to extract sufficient money from the community to defray the cost of defending of state and of enforcing the law it makes on the state behalf.

Samuel Edward Finer dalam bukunya Comperative Government sebagaimana dikutip oleh Inu Kencana Syafie, menyatakan bahwa istilah government, paling sedikit mempunyai empat arti: 5

a) menunjukkan kegiatan atas proses memerintah, yaitu melaksanakan kontrol atau pihak lain (the activity or the process of roverning).

b) menunjukkan masalah-masalah negara dalam mana kegiatan atau prosesdi atas dijumpai (states of affairs).

c) menunjukkan orang-orang (pejabat-pejabat) yang dibebani tugas-tugas untuk memerintah (people changed with the duty of governing).

d) menunjukkan cara, metode, atau sistem dengan mana suatu masyarakat tertentu diperintah (the manner, method or system by witch a particular society is governed)

\subsection{Pengawasan}

Pengawasan adalah suatu penilaian yang merupakan suatu proses pengukuran dan verifikasi dari serangkaian proses yang telah diselenggarakan secara berkelanjutan. Secara konsepsional pengawasan terdiri dari pengawasan fungsional, pengawasan internal, pengawasan masyarakat, yang ditandai system pengadilan dan pengawasan yang tertib, sidalmen/waskat, wasnal, wasmas, koordinasi, integrasi dan sinkronasi aparat pengawasan, terbentuknya sistem informasi pengawasan yang mendukung pelaksanaan tindak lanjut, serta jumlah dan kualitas auditor professional yang memadai, intensitas tindak lanjut pengawasan dan penegakan hukum secara adil dan konsisten. ${ }^{6}$

Dalam penyelenggaraan urusan pemerintahan, pemerintah daerah menyelenggarakan urusan pemerintahan yang menjadi kewenangannya yaitu urusan wajib dan urusan pilihan, kecuali urusan pemerintahan yang dalam peraturan perundang-undangan ditentukan menjadi urusan pemerintah yaitu politik luar negeri, pertahanan, keamanan, yustisi, moneter atau fiskal nasional, dan agama. Dalam suatu negara, terlebih dalam negara yang sedang membangun, pengawasan itu sangat penting, baik pengawasan secara vertikal, horizontal, eksternal, preventif maupun represif agar maksud dan tujuan yang telah ditetapkan dapat tercapai.

Dalam suatu negara, terlebih dalam negara yang sedang membangun, pengawasan itu sangat penting, baik pengawasan secara vertikal, horizontal, eksternal, preventif maupun represif agar maksud dan tujuan yang telah ditetapkan dapat tercapai.

\subsection{Perdagangan Manusia}

Definisi perdagangan manusia yaitu perdagangan yang obyeknya manusia (khususnya perempuan dan anak), dengan atau tanpa persetujuan orang bersangkutan, di dalam suatu negara atau ke luar negeri, dengan tujuan untuk dijadikan pekerja yang bersifat eksploitatif, selain itu umumnya mereka akan dipekerjakan sebagai

\footnotetext{
Ibid.

6 Nurcholis Hanif, Teori dan Praktik Pemerintahan dan Otonomi Daerah, Grasindo, Jakarta: 2007. HIm. 14.
} 
pekerja prostitusi dan perbudakan yang berkedok pernikahan (servile marriage). ${ }^{7}$

Merujuk dari protocol Perserikatan Bangsa-Bangsa (PBB), pengertian dari perdagangan manusia adalah: "Rekrutmen, transportasi, pemindahan, persembunyian atau penerimaan seseorang dengan ancaman atau penggunaan kekerasan atau bentuk tekanan lain seperti penculikan, pemaksaan, penipuan atau penyalahgunaan kekuasaan atau penerima/pemberian bayaran atau manfaat sehingga memperoleh persetujuan dari orang yang memegang kendali atas orang tersebut untuk dieksploitasi seperti prostitusi atau bentuk-bentuk eksploitasi sexual lainnya."

Berdasarkan definisi di atas, maka dapat dibentuk sebuah tabel sebagai indikator apakah suatu perbuatan itu termasuk dalam kejahatan perdagangan manusia pada tabel 2.1.

1) Faktor - Faktor Pendorong Perdagangan Manusia
Faktor eksternal yang mendorong perdagangan manusia antara lain:

a. Lemahnya peran dan kontrol pemerintah

b. Organisasi kejahatan transnasional

c. Perantara / calo yang berkedok lembaga pencari tenaga kerja

d. Pemerintah lokal dan berbagai perangkat hukum lainnya

e. Efek negatif globalisasi

Selain faktor-faktor eksternal yang mempengaruhi tumbuh suburnya perdagangan manusia, faktor-faktor internal juga merupakan salah satu penyebab terjadinya perdagangan manusia biasanya ditinjau dari aspek korban, sebagai berikut:

a. Kurangnya kewaspadaan

b. Kemiskinan

C. Hasrat materialistik

d. Budaya

Tabel 2.1

Indikator Perbuatan

\begin{tabular}{ccc}
\hline Proses & Cara & + \\
\hline Rekrutmen & Ancaman & Prostitusi \\
Transportasi & Pemaksaan & Pornografi \\
Pemindahan & Penculikan & Eksploitasi/kekerasan seksual \\
Persembunyian & Penipuan & Kerja paksa/kerja tanpa gaji yang adil \\
Penerimaan & Penyalahgunaan kekuasaan & Perbudakan
\end{tabular}

Sumber: 2000 UN Protocol to Prevent, Suppress and Punish Trafficking in Persons, especially Women and Children; Supplement to the UN Convention against Transnational Organized Crime and the UN Trafficking Protocol.

$7 \quad$ Wijers and Lap Chew, Trafficking in Women: Forced Labor, and Slavery Like Practices in Marriage. Domestic Labor and Prostitution: 2010. 


\subsection{Teori Perlindungan}

Hukum Teori perlindungan hukum merupakan salah satu teori yang sangat penting untuk dikaji, karena fokus kajianya adalah memberikan perlindungan hukum ini berasal dari bahsa Inggris, yaitu legal protection theory, sedangkan dalam bahasa Belanda disebut dengan theorie der rechtliche schutz.

Terkait dengan perlindungan hukum, Philipis M. Hadjon menyatakan sarana perlindungan hukum ada dua, yaitu : sarana perlindungan hukum preventif dan sarana perlindungan hukum respresif di Indonesia ditangani oleh badan-badan : Pengadilan dalam lingkungan Peradilan Umum, Instansi Pemerintah yang merupakan lembaga banding administrasi dan badan-badan khusus $^{8}$ Dalam kongres PBB pada Tahun 1985 di Milan tentang The Prevention of Crime and moment of Offenders, dikemukakan : hak-hak korban seyognyanya di lihat sebagai bagian integral dari keseluruhan sistem peradilan pidana ${ }^{9}$ Ini berarti, antara filosofis manusia selalu mencari perlindungan dari ketidak seimbangan yang dijumpainya baik yang menyangkut hak-haknya maupun melalui aturan-aturan sehingga tercapai kehidupan selaras bagi kehidupan. Hukum, menurut Isran, dalam hal ini hukum pidana, merupakan salah satu upaya untuk menyeimbangkan hal-hal tersebut. ${ }^{10}$

\subsection{Teori Pemidanaan}

Teori-teori pemidanaan berkembang mengikuti dinamika kehidupan masyarakat sebagai reaksi dari timbul dan berkembangnya kejahatan itu sendiri yang senantiasa mewarnai kehidupan sosial masyarakat dari masa ke masa. Dalam dunia ilmu hukum pidana itu sendiri, berkembang beberapa teori tentang tujuan pemidanaan, yaitu teori absolut (retributif), teori relatif (deterrence/utilitarian), teori penggabungan (integratif), teori treatment dan teori perlindungan sosial (social defence). Teori-teori pemidanaan mempertimbangkan berbagai aspek sasaran yang hendak dicapai didalam penjatuhan pidana. ${ }^{11}$

Menurut Leonard, teori relatif pemidanaan bertujuan mencegah dan mengurangi kejahatan. Pidana harus dimaksudkan untuk mengubah tingkah laku penjahat dan orang lain yang berpotensi atau cenderung melakukan kejahatan. Tujuan pidana adalah tertib masyarakat, dan untuk menegakan tata tertib masyarakat itu diperlukan pidana.

Pidana bukanlah sekedar untuk melakukan pembalasan atau pengimbalan kepada orang yang telah melakukan suatu tindak pidana, tetapi mempunyai tujuan-tujuan tertentu yang bermanfaat. Pembalasan itu sendiri tidak mempunyai nilai, tetapi hanya sebagai sarana untuk melindungi kepentingan masyarakat. Dasar pembenaran pidana terletak pada tujuannya adalah untuk mengurangi frekuensi kejahatan. Pidana dijatuhkan bukan karena orang membuat kejahatan, melainkan supaya orang jangan melakukan kejahatan. Sehingga teori ini sering juga disebut teori tujuan (utilitarian theory). ${ }^{12}$

Philipus M. Hadjon, Perlindungan Hukum Bagi Rakyat, Bina IImu, Surabaya: 1987. hlm. 10.

9 Banda Nawawi Arief, Beberapa Aspek Kebijakan Penegakan dan Pengembangan Hukum Pidana, PT Citra Aditya Bakti, Bandung: 1998. hlm. 53.

10 Koespamono Isran, Korban Kejahatan Perbankan, Cetakan Kedua, Bayumedia Publishing, Malang: 1995. hIm. 81

11 Dwidja Priyanto, Sistem Pelaksanaan Pidana Penjara Di Indonesia, PT. Rafika Aditama, Bandung: 2009. hlm. 22.

12 Ibid. hlm. 26. 
Adapun ciri pokok atau karakteristik teori relatif (utilitarian), yaitu :

1) Tujuan pidana adalah pencegahan (prevention);

2) Pencegahan bukan tujuan akhir tetapi hanya sebagai sarana untuk mencapai tujuan yang lebih tinggi yaitu kesejahteraan masyarakat;

3) Hanya pelanggaran-pelanggaran hukum yang dapat dipersalahkan kepada si pelaku saja (misal karena sengaja atau culpa) yang memenuhi syarat untuk adanya pidana;

4) Pidana harus ditetapkan berdasar tujuannya sebagai alat untuk pencegahan kejahatan;

5) Pidana melihat ke muka (bersifat prospektif), pidana dapat mengandung unsur pencelaan.

\section{Metode Penelitian}

\subsection{Pendekatan dan Jenis Penelitian}

Metode penelitian yang digunakan dalam penelitian ini adalah penelitian kualitatif yaitu menggambarkan atau menjelaskan permasalahan yang ada dengan memberikan jawaban atas permasalahan yang dikemukakan. ${ }^{13}$ yaitu menjelaskan tentang kondisi lapangan tentang aktifitas perdagangan manusia pada tahun 20122016.

\subsection{Lokasi Penelitian}

Kabupaten Karimun terbagi atas Tanjung Balai, Kecamatan Meral yang berbatasan di sebelah
Barat dengan Kecamatan Rangsang dan Kabupaten Bengkalis, sebelah Timur dengan Kelurahan Tebing, sebelah Selatan dengan Kecamatan Rangsang dan Kabupaten Bengkalis serta sebelah Utara berbatasan dengan Selat Singapore dan Selat Malaysia.

Adapun lokasi kedua adalah kota Batam, yang merupakan pusat industry dan perdagangan di provinsi Kepulauan Riau. Batam sudah terkenal sebagai jantung aktifitas perdagangan dan industry sejak era 1990an mengingat pesatnya perkembangan kota tersebut hingga sekarang, kota ini berbatasan langsung dengan Singapore.

\subsection{Jenis Data}

Adapun jenis data yang digunakan dalam penulisan penelitian ini adalah Data kualitatif, yaitu data yang diperoleh berupa keterangan-keterangan, Sedangkan sumber data yang digunakan dalam penulisan penelitian ini adalah sebagai berikut:

1. Data primer

Data Primer, adalah data dalam bentuk verbal atau kata-kata yang diucapkan secara lisan, gerak-gerik atau perilaku yang dilakukan oleh subjek yang dapat dipercaya, yakni subjek penelitian atau informan yang berkenaan dengan variabel yang diteliti atau data yang diperoleh dari responden secara langsung $^{14}$ Data yang diperoleh dari hasil observasi dengan cara wawancara.

2. Data Sekunder

Data sekunder adalah data yang diperoleh dari teknik pengumpulan data yang menunjang data primer. Dalam penelitian ini

13 Sugiyono, Metode Penelitian, Alfabeta, Bandung: 2009. hlm. 11

14 Arikunto. Suharsimi, Manajemen Penelitian, Rhineka Cipta, Jakarta: 2010. HIm. 22. 
diperoleh dari hasil observasi yang dilakukan oleh penulis serta dari studi pustaka. Dapat dikatakan data sekunder ini berasal dari dokumen-dokumen grafis seperti tabel, catatan, SMS, foto dan lainlain. Data yang diperoleh dari laporalaporan tertulis serta informasi tentang keadaan yang ada.

\subsection{Sumber Data}

Sumber data dalam penelitian ini adalah wawancara langsung dengan informan yang dianggap mengetahui dan memahami permasalahan yang ada dilapangan serta pihak yang turun langsung dalam melakukan pencegahan dan penanggulangan aktifitas tersebut. Informan yang diambil dalam penelitian ini adalah pihak Dinas Sosial Kabupaten Karimun dan Kota Batam, Komisi Perlindungan Anak Indonesia di Karimun dan Batam, LSM-LSM terkait yang membantu program pemerintah dan membuat program pendukung seperti Embun Pelangi dan Rumah Faye, dan beberapa Tokoh Masyarakat di Kabupaten Karimun dan Kota Batam.

\subsection{Teknik Pengumpulan Data}

a. Wawancara

Yaitu mengumpulkan data dengan cara mengajukan pertanyaan langsung kepada informan atau seorang ahli yang berwenang dalam suatu masalah yang dapat memberikan informasi sesuai dengan masalah yang diteliti.

b. Dokumentasi
Yaitu cara mengumpulkan data dari setiap arsip dan buku untuk menggali informasi tentang permasalahan yang diteliti.

c. Observasi

Yaitu teknik pengumpulan data dengan cara pengamatan langsung ke lapangan/ lokasi terdapatnya aktifitas tersebut.

\subsection{Teknik Analisa Data}

Teknik analisis data yang digunakan adalah analisis data kualitatif, yakni dengan menggunakn model analisis interaktif dimana penulis terjun langsung ke lokasi penelitian dan secara langsung berinteraksi dengan narasumber dengan tujuan mendapatkan informasi seakurat mungkin. ${ }^{15}$

Data yang telah dihimpun dianalisis secara deskriptif. Pemaparan data-data hasil wawancara dilakukan secara naratif. Data-data yang ada akan disajikan dalam bentuk angka-angka hasil akumulasi dari jawaban pertanyaan-pertanyaan yang telah penulis himpun.

\section{Hasil dan Pembahasan}

Perdagangan perempuan dan anak-anak di wilayah Kepri seperti Tanjung Pinang, Batam dan Karimun, telah menjadi lahan eksploitasi seksual, di mana mereka pada akhirnya akan dipekerjakan pada tempat hiburan seperti bar karaoke, diskotik dan juga spa/ panti pijat. Bisa dikatakan Kepri bukanlah 'pemasok', namun hanya sebagai media transit kegiatan tersebut. Meski hanya sedikit saja data yang dapat membuktikan hal ini, namun, berdasarkan informasi dari beberapa LSM dan

15 Bagong Suyanto, Metode Penelitian Sosial: Berbagai Alternatif dan Pendekatan, Kencana, Jakarta: 2005. hlm. 166. 
pihak terkait, Kepri memang dikenal sebagai wilayah pengirim.Sejak 2005, beberapa LSM local telah menyediakan layanan shelter kepada lebih dari 237 Orang per tahunnya. Sekitar $68,3 \%$ berasal dari Batam, 20,6\% berasal dari Karimun, dan 10,9\% berasal dari Tanjungpinang dan Bintan. Terdapat beberapa kendala yang menyulitkan penyelesaian permasalahan ini, pertama permasalahan budaya lokal, kedua regulasi yang kurang kuat, dan ketiga kurangnya aparat dalam menegakkan aturan.

Untuk Wilayah Batam telah dilakukan tindakan seperti, pertama, pada tahun 2004Pemerintah membangun sebuah pusat pelatihan yang di sebut "Batam Internasional Training Center". Di sini para buruh migran perempuan tersebut menjalani Pembekalan Akhir Pemberangkatan (PAP). Di sini mereka mendapatkan informasi tindakan apa yang dilakukan jika mereka mendapatkan masalah dari majikan, juga penjelasan berkaitan dengan suratsurat perjalanan dan masa tinggal di luar negeri. Kedua, Pembentukan Gugus Tugas Anti Traffiking berdasarkan Keputusan Walikota tahun 2005, yang memungkinkan adanya upaya pemberantasan trafficking di Batam yang lebih terkoordinasi. Gugus tugas ini beranggotaan perwakilan kantor-kantor dinas dan LSM. Ketiga, pemulangan korban trafficking di tangani oleh Dinas Sosial. Pemda, dengan dukungan International Organization for Migration (IOM), menyediakan shelter untuk tempat tinggal sementara dan menfasilitasi pemulangan korban trafficking.

Tanjungpinang dan Bintan melakukan Sosialisasi akan perdagangan orang sebagai pelanggaran HAM dan tindak kriminal termasuk hal yang baru di Tanjung Pinang, walaupun kota ini telah menjadi kota transit dan tujuan selama beberapa tahun. Biasanya pemda melihat trafficking sebagai permasalahan warga pendatang dan bagian dari suatu tindak pidana. Januari 2006, pemda kota Tanjungpinangtelah membentuk Gugus tugas kota berdasarkan keputusan Walikota No. 24 tahun2006. Dan Karimun, telah menjalankan upaya dengan membentuk Gugus Anti Trafficking berdasarkan keputusan Bupati No 02.A Tahun 2005, dan berdasarkan aturan tersebut, telah dilakukan beberapa razia rutin dan dadakan yang juga dimotori oleh pemuka agama setempat.

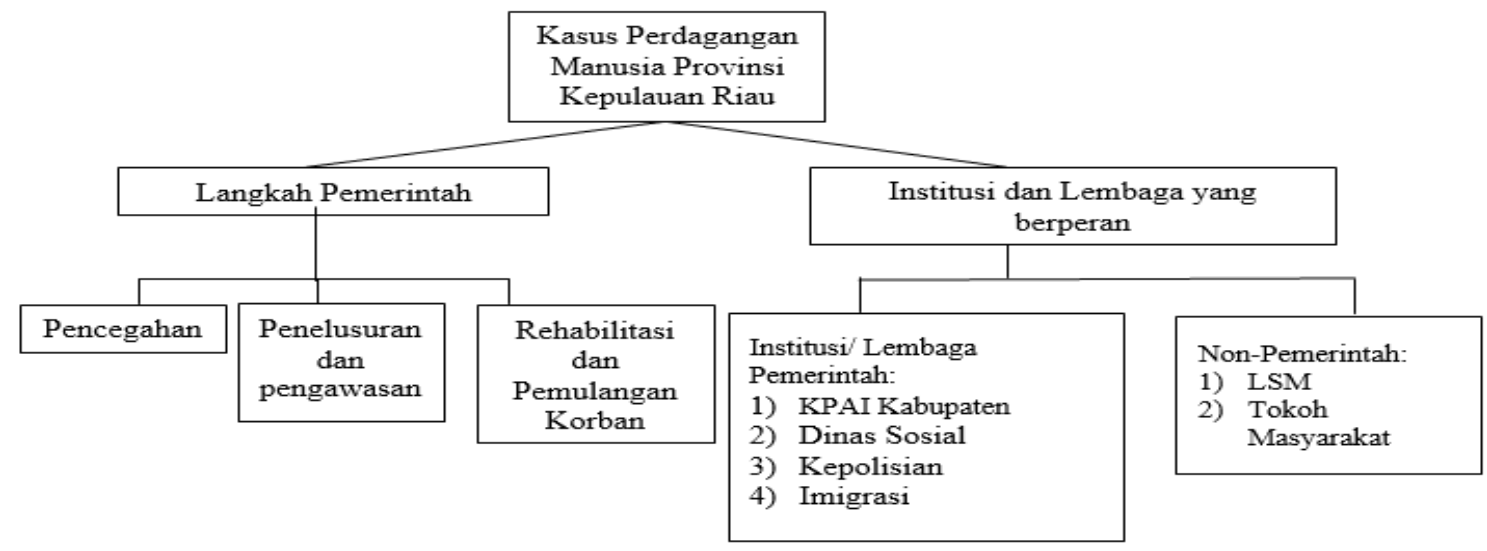


Beberapa permasalahan jika diperjelas per poin adalah sebagai berikut:

a. Batam dan Karimun sebagai wilayah terluar dan terdekat Kepri untuk bersentuhan langsung dengan Negara luar memiliki ancaman berupa eksploitasi besar-besaran tiap tahunnya yang menunjukkan angka yang mengalami peningkatan

b. implikasi dari ekspolitasi ini bisa jadi akan berimbas pada sektor ekonomi, politik dan juga sosial di wilayah Batam dan Karimun

c. Formulasi kebijakan pemerintah yang terkesan setengah-setengah dan masih lemahnya kontrol terhadap pintu Perdagangan manusia dapat berakibat pada peningkatan secara massif dan berkelanjutan.

d. Perdagangan manusia menjadi isu yang sulit diatasi ketika 'korban' perdagangan tidak melaporkan kejadian dan atau malah terus menjalankan praktik ini karena minimnya keterampilan dan tingginya biaya dan gaya hidup.

Hampir semua pola perdagangan ilegal dan perbudakan memerlukan tanggapan bilateral dan multilateral. Artinya, dengan melibatkan beberapa negara dengan yurisdiksi yang berbedabeda. Perlu kerjasama dan peraturan bersama, misalnya tentang pemulangan korban dan peradilan pidana. Dengan demikian, instrumeninstrumen penting dimaksud dapat dimanfaatkan guna mencapai upaya memerangi perdagangan manusia dengan lebih efektif.
Untuk mengatasi perdagangan manusia, pertama, pada level komunitas, memberikan pelatihan padat karya kepada komunitaskomunitas yang belum mempunyai kemampuan untuk meningkatkan perekonomian komunitas dan memberikan pengetahuan tentang perdagangan manusia. Kedua, pada level nasional yaitu dengan menegakkan UU Nomor 21 Tahun 2007, meningkatkan keamanan penjagaan di perbatasan negara, baik darat maupun laut dan udara, meningkatkan keamanan di imigrasi (izin keluar negeri), meningkatkan lapangan kerja, meningkatkan taraf pendidikan, menutup tempat-tempat yang berpotensi terjadi eksploitasi seksual. Ketiga, pada level luar negeri antara lain dengan meningkatkan hubungan kerja sama antar negara, mengadakan operasi bersama, dan membentuk organisasi untuk memerangi perdagangan orang. ${ }^{16}$

Undang-Undang RI Nomor 21 Tahun 2007 Pasal 1 ayat 1 tentang pemberantasan tindak pidana perdagangan orang, perdagangan Perdagangan Orang adalah tindakan perekrutan, pengangkutan, penampungan, pengiriman, pemindahan, atau penerimaan seseorang dengan ancaman kekerasan, penggunaan kekerasan, penculikan, penyekapan, pemalsuan, penipuan penyalahgunaan kekuasaan atau posisi rentan, penjeratan utang atau memberi bayaran atau manfaat, sehingga memperoleh persetujuan dari orang yang memegang kendali atas orang lain tersebut, baik yang dilakukan di dalam negara

16 Bibit Santoso, Menyikapi Perdagangan Manusia, Kompas tanggal 29 Maret 2017. hlm. 6. 
maupun antar negara, untuk tujuan eksploitasi atau mengakibatkan orang tereksploitasi. ${ }^{17}$

Tentu Kekhususan dari UU 21 Tahun 2007 ini lebih optimal dan lebih siap mulai dari norma serta ancaman yang mengatur bagi pelaku perdagangan orang, bisa di lihat dalam Dalam rumusan Pasal 1 angka 4 UU No 21 Tahun 2007, pelaku adalah setiap orang perseorangan atau korporasi yang melakukan tindak pidana perdagangan orang. Dalam Pasal 2 sampai dengan 18 yang di sertai dengan ancaman, undang-undang ini secara tegas merumuskan sanksi terhadap pelaku perdagangan orang. Berdasarkan pasal pasal tersebut, dapat dikategorikan beberapa pelaku Tindak Pidana Perdagangan Orang, yaitu18:

Pertama, Agen perekrutan Tenaga Kerja (legal atau illegal) yang membayar agen/ calo untuk mencari buruh di desa-desa, mengelola penampungan, mengurus identitas serta KTP dan dokumen pejalanan, memberikan pelatihan dan pemeriksaan medis serta menempatkan buruh dalam kerjaannya di Negara tujuan. Meskipun tidak semua, namun sebagian PJTK terdaftar melakukan tindakan demikian.

Kedua, Agen/calo (mungkin orang asing) yang datang ke suatu desa, tetangga, teman, bahkan kepala desa, tokoh masyarakat, tokoh adat, maupun tokoh agama. Agen dapat bekerja secara bersamaan untuk PJTK terdaftar/tidak terdaftar, guna memperoleh bayaran untuk tiap buruh yang direkrutnya.
Ketiga, Majikan yang memaksa buruh bekerja dalam kondisi eksploitatif, tidak membayar gaji, menyekap buruh di tempat kerja, melakukan kekerasan seksual atau fisik terhadap buruh.

Keempat, Pemerintah dalam pasal 19, yang terlibat dalam pemalsuan dokumen memberikan atau memasukkan keterangan palsu pada dokumen resmi baik dokumen yang dikeluarkan instansi pemerintah maupun instansi lain serta pemberian oleh pihak yang berwenang serta

Kelima, Pemilik/pengeloa rumah bordil yang memaksa perempuan untuk bekerjadi luar kemauan dan kemampuannya, tidak membayar gaji atau merekrut dan mempekerjakan anak yang belum berusia 18 tahun. Bahwa untuk melaksanakan ketentuan Pasal 58 ayat (1) Undang-Undang Nomor 21 Tahun 2007 tentang Pemberantasan Tindak Pidana Perdagangan Orang, di perkuat lagi dengan Peraturan Presiden No. 69 Tahun 2008 tentang Gugus Tugas Pencegahan dan Penanganan Tindak Pidana Perdagangan Orang. Untuk Gugus Tugas di daerah, Menteri Dalam Negeri mengeluarkan Surat Edaran Departemen Dalam Negeri Nomor 560/1134/PMD/2003 yang ditujukan kepada Gubernur, Bupati, dan Walikota seluruh Indonesia. Dalam surat edaran tersebut diarahkan bahwa focal point pelaksanaan penghapusan perdagangan orang di daerah dilaksanakan oleh unit kerja di jajaran pemerintah daerah yang mempunyai kewenangan menangani urusan anak

17 Pasal 1 Undang - Undang Nomor 21 Tahun 2007 Tentang Pemberantasan Tindak Pidana Perdagangan Orang

18 file://ID:/PERDAGANGAN\%20ORANG\%20JURNAL\%202\%20(PDF).pdf 
melalui penyelenggaraan pertemuan koordinasi kedinasan di daerah dengan tujuan menyusun standar minimum dalam pemenuhan hak-hak anak, pembentukan satuan tugas penanggulangan perdagangan orang di daerah, melakukan pengawasan ketat terhadap perekrutan tenaga kerja, dan mengalokasikan dana APBD untuk keperluan kegiatan ${ }^{19}$ Januari 2006, pemda kota Tanjungpinang telah membentuk Gugus tugas kota berdasarkan keputusan Walikota No. 24 Tahun 2006. Dan Karimun, telah menjalankan upaya dengan membentuk Gugus Anti Trafficking berdasarkan keputusan Bupati No 02.A Tahun 2005,

Sejak diundangkannya Undang-undang

No. 21 Tahun 2007 tentang Pemberantasan Tindak Pidana Perdagangan Orang serta beberapa ketentuan regulasi yang sebagai pendukung Secara umum ketentuan KUHP dapat memperkuat berlakunya ketentuan-ketentuan antitrafficking, Eksploitasi seksual yang mungkin timbul dalam kegiatan perdagangan orang bisa dijerat dengan Pasal 285, 287, 288, 289, 290 ayat (2) dan (3), 291, 293, 294, 295 ayat (1) dan (2), 296, 297, 298, dan Pasal 506 KUHP. Serta ketentuan Pasal 65 UU Nomor 39 Tahun 1999 tentang Hak Asasi Manusia. Pasal 10 UU Nomor 1 Tahun 1951 tentang Pernyataan Pemberlakuan UU Nomor 12 Tahun 1948 yang memberikan perlindungan kepada hak-hak tenaga kerja, Pasal 3 UU Nomor 20 Tahun 1999 tentang Pengesahan Konvensi ILO Nomor 138 Tahun 1973 Mengenai Usia Minimum untuk Diperbolehkan Bekerja, UU

Nomor 36 Tahun 2009 tentang Kesehatan yang meskipun tidak membahas secara khusus tentang perdagangan manusia, tetapi sangat mungkin korban trafficking mendapat perlakuan berupa pengambilan organ tubuh untuk diperjual belikan. Dan beberapa Regulasi pendukung lainnya mempunyai korelasi terhadap kasus perdagangan orang

Semua regulasi ini tentu memberikan harapan baru dalam rangka penanganan kasus perdagangan orang yang semakin marak dan sudah merupakan kejahatan yang serius serta luar biasa dan juga pengingkaran terhadap Hak Asasi Manusia sehingga pencegahan dan pemberantasannya harus selalu diupayakan Bahkan saat ini, Indonesia telah meratifikasi United Nations Convention Against Transnational Organized Crime (UNCATOC) dengan Undang-undang Nomor 5 Tahun 2009, tanggal 1 Januari 2009 Dengan telah diratifikasinya Konvensi PBB tersebut, berarti Indonesia telah benar-benar merupakan bagian dari upaya penanggulangan tindak pidana perdagangan orang secara global

Sinergitas pemerintah r pusat
(kementerian/ lembaga terkait) lembaga
Internasional, lembaga pendidikan dengan
pemerintah daerah dan masyarakat di daerah-
daerah yang rentan terjadi perdagangan orang
menjadi kunci dalam menekan tindak pidana
perdagangan orang. Pasal 15 Peraturan Presiden
RI No. 69 Tahun 2008 Tentang Gugus
pencegahan dan Penanganan Tindak Pidana
Perdagangan Orang Untuk menjamin sinergitas

19 Komnas Perempuan, Penanganan Kasus-kasus Kekerasan Terhadap Perempuan Di Lingkungan Peradilan Umum. Australian Government (AusAID): 2009. hIm. 24. 
dan kesinambungan langkah-langkah pemberantasan tindak pidana perdagangan orang secara terpadu, Gugus Tugas Pusat, Gugus Tugas Provinsi, dan Gugus Tugas Kabupaten/Kota melakukan koordinasi dan hubungan secara langsung dengan instansi terkait dan pihak terkait lainnya untuk menyusun kebijakan, program, kegiatan, dalam bentuk Rencana Aksi Nasional dan Rencana Aksi Daerah. Mencari formulasi- formulasi yang mampu menyentuh akar persoalan mulai dari dasar persoalan sampai solusi dan alternatif bagi korban perdagangan orang, Hanya dengan bergandengan tangan semua pemangku kebijakan, penegak hukum, organisasi masyarakat, lembaga swadaya masyarakat, organisasi profesi, dan peneliti/akademisi mempunyai peran penting dalam upaya pencegahan tindak pidana perdagangan orang.

\section{Penutup}

\subsection{Kesimpulan}

Sebagai bagian dari transnasitional organized crime. Atau Sebagai kejahatan yang pada umumnya sudah terorganisir terususn dengan rapi, dan persoalan yang sangat kompeks yang mempunyai korelasi antara satu dengan yang lain ketika persoalan hukum terjadi pada level perdagangan orang, tentu pada akhirnya di butuhkan perhatian semua pihak perdagangan orang tidak dapat diperangi secara parsial oleh masing-masing negara. Mengatasi permasalahan perdagangan orang tidak hanya melibatkan satu lembaga, penegak hukum, organisasi masyarakat, lembaga swadaya masyarakat, organisasi profesi, dan peneliti/akademisi mempunyai peran penting dalam upaya pencegahan tindak pidana perdagangan orang memandang bahwa daerah punya peran yang signifikan dalam mencegah terjadinya kejahatan perdagangan orang.

\subsection{Saran}

Pemerintah pusat dan daerah harus selalu melakukan sosialisasi tentang pengaturan bagaimana sistem pemberantasan kejahatan perdagangan orang kepada masyarakat luas sebab masih banyak masyarakat yang belum paham dengan kejahatan perdagangan orang dan masyarakat juga harus dapat ikut serta bertanggung jawab sebagaimana pemerintah dan negara dalam memberantas perdagangan orang terutama Provinsi-provinsi di Indonesia yang menjadi sumber maupun tujuan perdagangan manusia khususnya Kepri berlandaskan pada prinsip-prinsip perlindungan dan penghormatan atas Hak Asasi Manusia , non-diskriminasi, bukan lagi melihat mereka pendatang atau bukan pendatang karena pada hakekatnya kita memiliki andil dan tanggung jawab untuk ikut memberantas kejahatan perdagangan orang atau trafficking dengan menggunakan Undang-undang No. 21 Tahun 2007 tentang Pemberantasan Tindak Pidana perdagangan Orang serta regulasi yang berhubungan dengan kasus perdagangan orang Memeriksa kembali Nota Kesepahaman dengan Negara-negara yang menjadi tujuan perdagangan 
untuk memasukkan perlindungan terhadap mengawal terjadinya kejahatan tehadap korban.sebagai bentuk tindakan preventif dalam perdagangan orang.

\section{DAFTAR PUSTAKA}

Arief, Barda Nawawi. Beberapa Aspek Kebijakan Penegakan dan Pengembangan Hukum Pidana. Bandung: PT Citra Aditya Bakti, 1998.

Budiardjo, Miriam. Dasar-Dasar IImu Politik. Jakarta: Gramedia Pustaka Indonesia, 2000.

Chew, Wijers and Lap. Trafficking in Women: Forced Labor, and Slavery Like Practices in Marriage. Domestic Labor and Prostitution. 2010.

Hadjon, Philipus M. Perlindungan Hukum Bagi Rakyat. Surabaya: Bina IImu, 1987.

Hanif, Nurcholis. Teori dan Praktik Pemerintahan dan Otonomi Daerah. Jakarta: Grasindo, 2007.

Isran, Koespamono. Korban Kejahatan Perbankan, Cetakan Kedua. 1995: Bayumedia Publishing, Malang.

Kencana, Inu. Pengantar IImu Pemerintahan. Bandung: Refika Aditama, 2005.
Perempuan, Komnas. Penanganan Kasus-kasus Kekerasan Terhadap Perempuan Di Lingkungan Peradilan Umum. Australian Government (AusAID), 2009.

Priyanto, Dwidja. Sistem Pelaksanaan Pidana Penjara Di Indonesia. Bandung: Rafika Aditama, 2009.

Santoso, Bibit. Menyikapi Perdagangan Manusia. Jakarta, Maret Rabu, 2017.

Sugiyono. Metode Penelitian. Bandung: Alfabeta, 2009.

Suharsimi, Arikunto. Manajemen Penelitian. Jakarta: Rhineka Cipta, 2010.

Suriansyah, Murhaini. Manajemen Pengawasan Pemerintah Daerah. Jakarta: Pustaka Pelajar, 2014.

Suyanto, Bagong. Metode Penelitian Sosial: Berbagai Alternatif dan Pendekatan. Jakarta: Kencana, 2005. 